\title{
Optimization of meat analog production from concentrated soy protein and yam (Xanthosoma sagittifolium) powder using pasta machine
}

\author{
1, ${ }^{*}$ Lindriati, T., ${ }^{1}$ Herlina, H., ${ }^{2}$ Arbiantara, H. and ${ }^{2}$ Asrofi, M. \\ ${ }^{1}$ Department of Agricultural Product Technology, University of Jember, Kalimantan Street No. 37. Post \\ Code 68121, Jember, East Java, Indonesia \\ ${ }^{2}$ Department of Mechanical Engineering, University of Jember, Kalimantan Street No. 37. Post Code \\ 68121, Jember, East Java, Indonesia
}

\begin{abstract}
Article history:
Received: 27 October 2019

Received in revised form: 18

December 2019

Accepted: 20 December 2019

Available Online: 20

February 2020
\end{abstract}

Keywords:

Meat analog,

Xanthosoma sagitifolium

powder,

Response surface method,

Fourier transform infrared,

Household pasta machine

DOI:

https://doi.org/10.26656/fr.2017.4(3).357

\begin{abstract}
The objectives of this study were to determine the effect of Xanthosoma sagitifolium powder (XSP), mixing time and water on meat analog characters and to optimize these parameters in meat analog production using Response Surface Methodology with BoxBehnken design. Meat analog is produced from mixing XSP and concentrated soy protein using a household pasta machine. The observation was made at the range of XSP proportion $0-80 \%$, mixing time $6-18$ mins and water addition $70-150 \%$. Fourier Transform Infra-red (FTIR) was employed to determine the alteration of the functional bond. The results of FTIR observation showed that the highest intensity obtained when XSP proportion, mixing time and water addition are $20 \%, 9$ mins and $140 \%$ respectively. The experimental data obtained from the Box-Behnken design was in accordance with the second order polynomial equation. Moreover, the 3D response surface derived from mathematical models was used to optimize the production condition. The optimum production conditions are XSP proportion of 30\%, water addition of $140 \%$ and mixing time of 12 mins which produced meat analog having WHC of $145.3542 \pm 5.7384 \%$, OHC of $43.7869 \pm 7.8725 \%$ and texture of $90.32 \pm 0.37 \mathrm{gr} / \mathrm{mm}$.
\end{abstract}

\section{Introduction}

There has been growing food demand including protein-based diet driven by the increasing world population. In several developing countries, there are problems related to animal protein malnutrition. In addition, the awareness of healthy food has shifted the consumption trend from animal protein towards plant protein. Meat analog is a vegetable protein-based food texturized to imitate meat products (Sheard et al., 1984). This diet becomes suitable for vegetarian diet and is considered as healthy food. Meat analog becomes more superior compared with animal meat based on the ability to reduce the risks of heart disease and cancer. Meat analog usually is made from soy protein as a major component and is fabricated with extrusion cooking to produce fiber-like structure (Lin et al., 2000; Yao et al., 2004).

The fiber-like structure in meat analog depends on the material of its components, extrusion conditions and moisture content. The combination of temperature enhancement and shear rates during screw rotation results in protein and carbohydrate melting (Krintiras,
2015). Extrusion machines are commonly large-scale machines and cannot be utilized in daily cooking. However, household pasta machine is a simple extrusion machine which has been used in daily cooking activities for making pasta at a common household kitchen. The application of this machine in meat analog production facilitates the meat analog provision and ease of consumption.

Furthermore, the addition of carbohydrate into a meat analog matrix probably increases texture and fibrous characteristic. Xanthosoma sagittifolimum yam is a good source of carbohydrate which can be cultivated under less favorable land conditions. Yam can be normally consumed boiled, fried, steamed or roasted. Besides its high starch content of $74.66 \pm 0.66$ to $80.46 \pm 0.62 \%$, yam has various types of phytochemicals (Senanayake et al., 2012). The most predominant phytochemicals are diosgenin, saponin, dioscorine, alkaloid and flavonoid which make yam offer diverse health benefits. The addition of Xanthosoma sagittifolimum powder (XSP) in meat analog production is expected to increase the physical properties and to improve functional properties of health. 
The chemical bonds performed in meat analog matrix are disulfide bonds, hydrogen bonds and hydrophobic interaction (Hager, 1984). The bond is performed in protein-protein interaction to form matrix structure in meat analog. Protein content that increases in meat analog results in fine structure (Maurice and Stanley, 1978). The carbohydrate content supports the structure and improves the texture of meat analog (Sheard et al., 1984; Rareunrom et al., 2008). The percentage of soy protein isolate increases from $20-80 \%$ of expansion ratio but reduces cutting force and fibrous characteristic (Rareunrom et al., 2008). There are considerable discrepancies in the appearance of the resulting product, between low moisture (up to $35 \%$ ) and high moisture (over 50\%) extrusion. Although the extrudates have differed in appearance, protein-protein interaction which is contributed in meat analog structure remains unchanged (Chiang, 2007). Consequently, water addition probably affects its texture and appearance.

The first objective of this study is to examine the alteration of chemical bonds in meat analog matrix driven by the variation on XSP proportion, mixing time and water addition. The observations are executed using Fourier Transform Infrared (FTIR). The second objective is to determine the optimum parameter from XSP proportion, mixing time and water addition based WHC, $\mathrm{OHC}$ and texture data. The optimization is implemented with RSM (Response Surface Methodology). RSM is an effective statistical technique which can reduce the period and number of experiments. The meat analog in this research is developed using a household pasta machine.

\section{Materials and methods}

\subsection{Materials}

The raw materials used were Concentrated Soy Protein (CSP) is obtained from "NURA" (local shop) containing $66.14 \%$ protein, $0.16 \%$ lipid, $5.75 \%$ water, $4.43 \%$ ash and $27.94 \%$ carbohydrate. Xanthosoma sagittifolium powder (XSP) was made from Xanthosoma sagittifolimum tubers with modification on dipping solution wherein sodium chloride $200 \mathrm{ppm}$ was used rather than sodium metabisulphite of $20 \mathrm{ppm}$ (Owuamanam, 2010). The XSP contains $2.37 \%$ protein, $0.33 \%$ lipid, $8.27 \%$ water, $4.42 \%$ ash and $84.61 \%$ carbohydrate. Moreover, mineral water ("Aqua") is added to adjust moisture contain.

\subsection{Design experiment}

The research was divided into two stages. The objective of the first stage was to determine the alteration of chemical bonds using FTIR. Observations were made on the variations of XSP proportion $(0,20,40,60$ and $80 \%)$, mixing time $(6,9,12,15$ and 18 mins) and water addition $(80,100,120$ and $140 \% \mathrm{w} / \mathrm{w})$. The aim of the second stage was to determine the optimum condition in the production of meat analog by using RSM method; furthermore, Box-Behnken design was chosen. There were three independent variables consisting of XSP proportion (X1), mixing time (X2) and water addition (X3). After randomization using Box-Behnken design, fifteen experimental conditions were tested and optimized. The randomization result was shown in Table 1. The response variables were $\mathrm{WHC}, \mathrm{OHC}$ and texture. The RSM was run using Minitab V 17.0 for Windows.

Table 1. Box-Behnken design with coded levels and actual levels

\begin{tabular}{ccccccc}
\hline & \multicolumn{3}{c}{ Coded Level } & \multicolumn{3}{c}{ Actual Level } \\
\cline { 2 - 7 } & $\mathrm{x}_{1}$ & $\mathrm{x}_{2}$ & $\mathrm{x}_{3}$ & $\begin{array}{c}\mathrm{x}_{1} \\
(\%)\end{array}$ & $\begin{array}{c}\mathrm{x}_{2} \\
(\mathrm{Min})\end{array}$ & $\begin{array}{c}\mathrm{x}_{3} \\
(\%)\end{array}$ \\
\hline 1 & -1 & 1 & 0 & 0 & 18 & 110 \\
2 & 0 & 1 & 1 & 40 & 18 & 140 \\
3 & 0 & 0 & 0 & 40 & 12 & 110 \\
4 & 1 & 1 & 0 & 80 & 18 & 110 \\
5 & -1 & 0 & -1 & 0 & 12 & 80 \\
6 & -1 & 0 & 1 & 0 & 12 & 140 \\
7 & 1 & 0 & 1 & 80 & 12 & 140 \\
8 & 1 & 0 & -1 & 80 & 12 & 80 \\
9 & 0 & 1 & -1 & 40 & 18 & 80 \\
10 & 0 & -1 & -1 & 40 & 6 & 80 \\
11 & 0 & 0 & 0 & 40 & 12 & 110 \\
12 & 0 & 0 & 0 & 40 & 12 & 110 \\
13 & -1 & -1 & 0 & 0 & 6 & 110 \\
14 & 1 & -1 & 0 & 80 & 6 & 110 \\
15 & 1 & -1 & 1 & 80 & 6 & 140 \\
\hline
\end{tabular}

The meat was made wherein, XSP was blended with CSP to obtain varied proportions. Water $\left(80^{\circ} \mathrm{C}\right)$ then was added in the extruder according to the research design. Afterwards, the dough was mixed and blended for a certain duration using household pasta machine (Healthy Power Noodle, Fastworld) then extruded through the die which has been modified. The extrusion process was classified as cool extrusion. Variations of XSP concentration, water addition and mixing time are applied according to the research design. After the extrusion process, the meat was cooked with $100^{\circ} \mathrm{C}$ steam for 30 mins and then it was dried in a regulating oven at $50^{\circ} \mathrm{C}$ for $20 \mathrm{hrs}$.

\subsection{FTIR analysis}

Samples for FTIR spectroscopy were prepared by drying meat analog at $50^{\circ} \mathrm{C}$ for 20 hrs to later was pulverized into a fine powder. Two milligrams of powder were mounted in the sample holder of the FTIR 
machine (Alpha-Bruker) and spectra were observed in the range $4000-450 \mathrm{~cm}^{-1}$.

\subsection{Texture analysis}

The dry meat analog was rehydrated by cooking in boiling water for 15 mins. The texture of meat analog was determined by using Rheotex Type of SD-700 (Sun Scientific Co-LTD); moreover, the penetrations of head was set at $0.15 \mathrm{~mm}$, ten measurements were conducted for each sample. The texture was reported as gram $/ \mathrm{mm}$.

\subsection{Water and oil - holding capacity (WHC and OHC).}

This method was used with slight modifications (Chau, 1997). One gram of dry meat analog was stirred in $10 \mathrm{~mL}$ of distilled water or coconut oil (using "Dorang" local product). Vortex was used in 2 mins. The dispersion was then centrifuged at $3000 \mathrm{rpm}$ for $30 \mathrm{mins}$. WHC or $\mathrm{OHC}$ was expressed as the weight of water or oil held by $1 \mathrm{~g}$ of the sample.

\section{Results and discussion}

\subsection{The effect of XSP proportion on FTIR spectra}

Figure 1 shows that 20\% XSP meat analog has the highest intensity in the range of $3500-3200 \mathrm{~cm}^{-1}$ and $1750-1250 \mathrm{~cm}^{-1}$ which is almost as high as $0 \%$ and $40 \%$ of XSP, and the lowest intensity is obtained from meat analog with $80 \%$ of XSP proportion. These areas represent amide $\mathrm{A}$ and $\mathrm{B}, \mathrm{OH}$ stretch, $\mathrm{NH}$ bend, $\mathrm{NH}_{2}$ bend, ring aromatic stretch, $\mathrm{C}=\mathrm{C}$ stretch, and $\mathrm{C}=\mathrm{O}$ stretch. These are the characteristics of FTIR protein spectra (Kong and $\mathrm{Yu}, 2007)$. After XSP proportion is varied from $0 \%-40 \%$, the interaction in the meat analog matrix will be controlled by protein-protein interaction.
When XSP is added to $20 \%$, the highest interaction was obtained.

In the range of $1158-1080 \mathrm{~cm}^{-1}$, the highest intensity is obtained from meat analog with $80 \%$ of XSP proportion, followed with $20 \%$ and $60 \%$ of XSP (Figure $1)$. The lowest intensity is obtained from meat analog with $0 \%$ of XSP proportion. These areas represent $\mathrm{C}-\mathrm{OH}$ stretching in carbohydrate molecule (Huang et al., 2006). The $20 \%$ of XSP addition had intensity band almost as high as $60 \%$ of XSP.

According to Figure 1, it can be presumed that the interaction between carbohydrate and protein is not a permanent bond, but it is a repulsive interaction wherein the expansion of the protein-protein matrix is supported by the existence of carbohydrate. Starch is distributed into the protein and fibrous matrix is not incorporated into the protein fiber (Noguchi, 1989). The role of carbohydrate is stabilized by the labile hydrophobic interactions in a protein-protein matrix whereas the microscopic work shows that carbohydrate gel acts as the cement in the protein matrix (Coomaraswamy and Flint, 1973). The optimum interaction is obtained when XSP is added to $20 \%$ in which the FTIR spectrum has the highest intensity.

There is a shift to the right of the peak in the area of $1158-1080 \mathrm{~cm}^{-1}$ from the XSP addition of $0 \%$ to $40 \%$. Once the XSP addition increased from $40 \%$ to $80 \%$ peaks, it does not shift. The shifts of absorption bands are probably related to interactions between the functional groups (Bodirlau and Teaca, 2009). The addition of XSP into meat analog matrix is probably shifted the protein-carbohydrate interaction especially in the area of $\mathrm{C}-\mathrm{OH}$ stretching. It is presumable that the

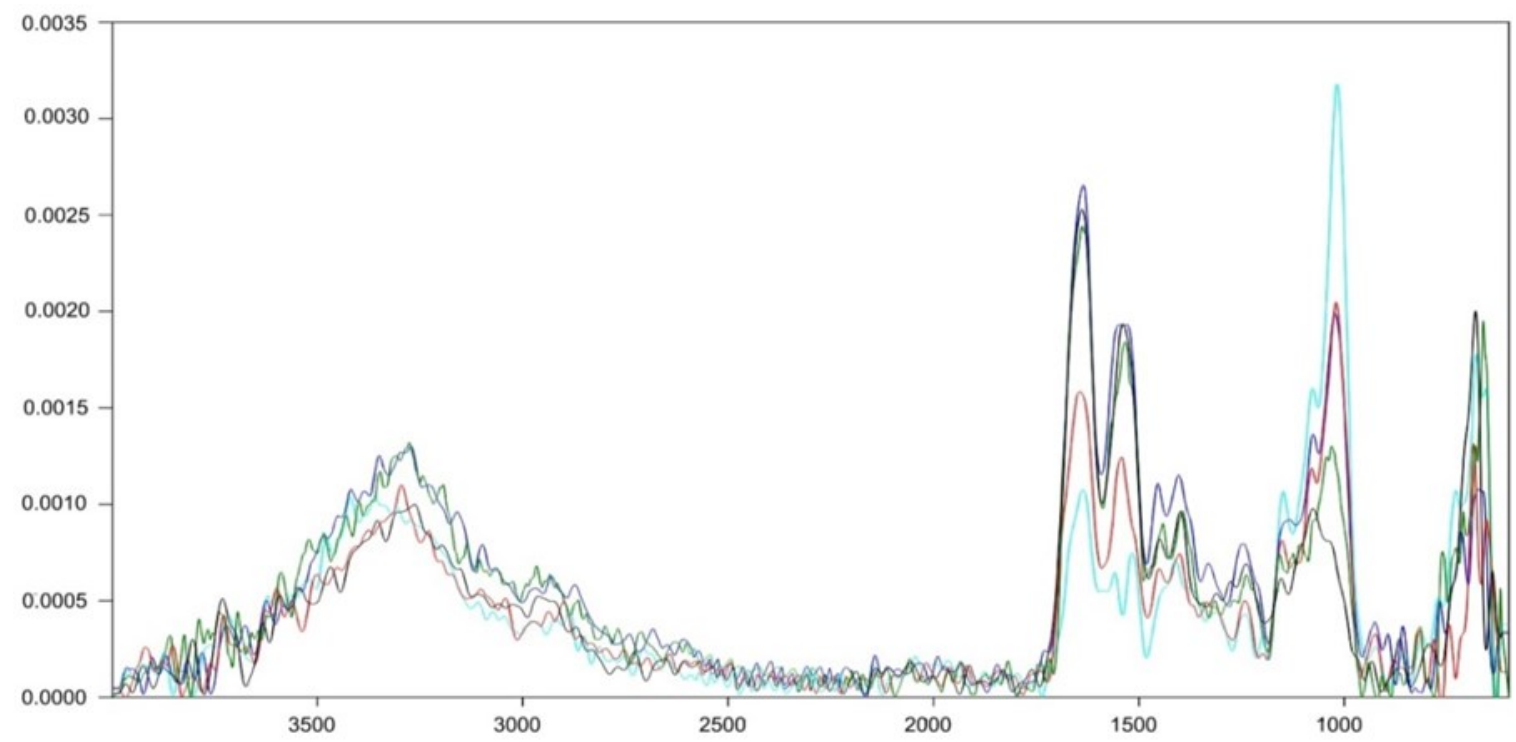

Figure 1. Spectral comparation of meat analog with $120 \%$ water addition and a 12 -minute mixing time from different levels of XSP proportion (Note: the y axis is absorbance units; the $\mathrm{x}$ axis is wavenumber $\mathrm{cm}^{-1} ;---=0 \% ;---=20 \%$; --- $=40 \%$; --- $=60 \%$; $---=80 \%)$. 


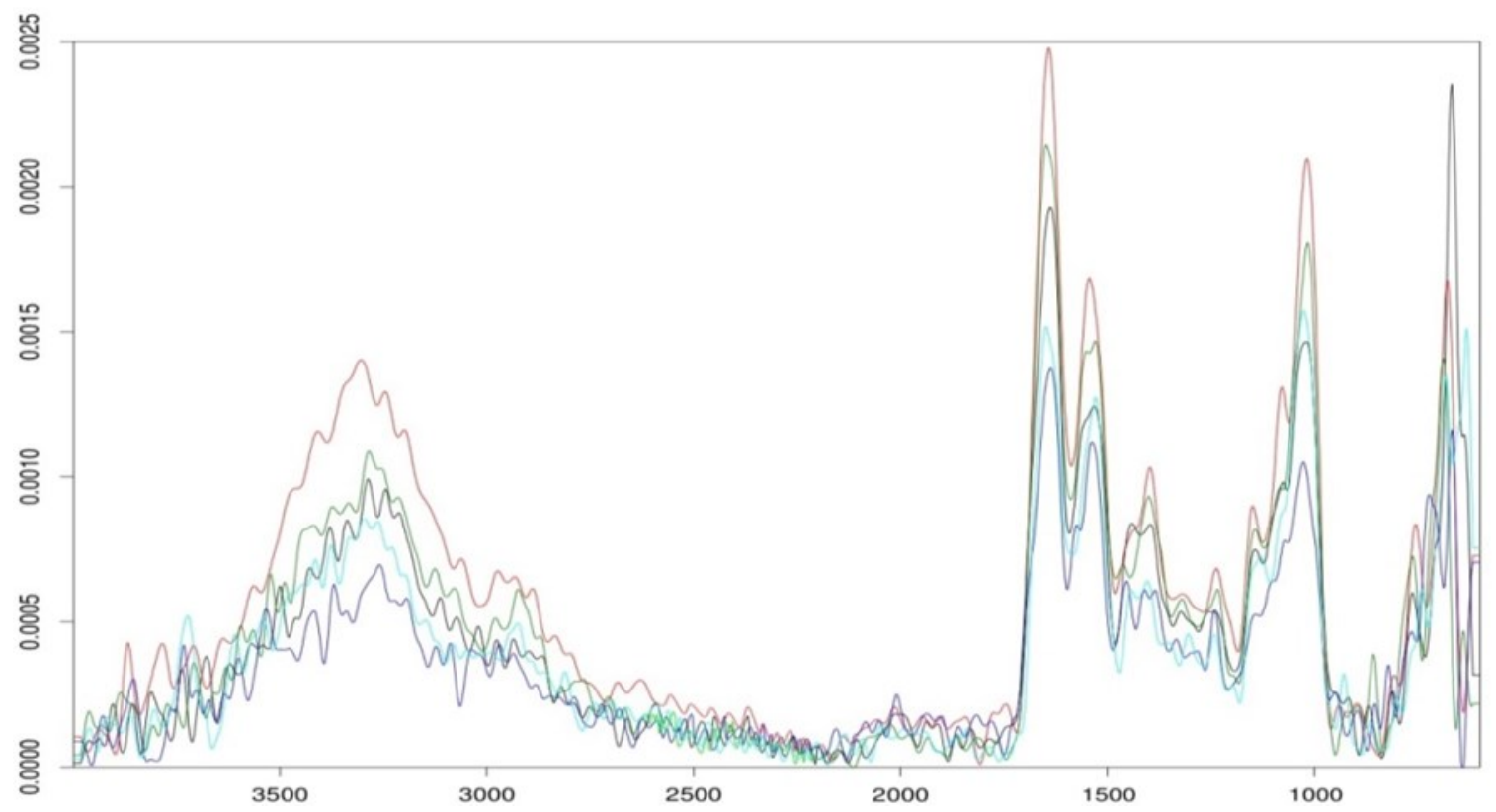

Figure 2. Spectral comparation of meat analog from 30\% XSP and 120\% water addition with different levels of mixing time (Note: the $\mathrm{y}$ axis is absorbance units; the $\mathrm{x}$ axis is wavenumber $\mathrm{cm}-1 ;---=0 \% ;---=20 \% ;---=40 \% ;---=60 \%$; --- $=6 \mathrm{mins}$; --= 9 mins; --- = 12 mins; --- = 15 mins; --- = 18 mins).

interaction of carbohydrate-protein effects on $\mathrm{C}-\mathrm{OH}$ stretch in the carbohydrate molecule.

\subsection{The effect of mixing time on FTIR spectra}

The increase of mixing time from $6-9$ mins, enhanced intensity of FTIR spectra as it is clearly shown in the range of $3500-3000 \mathrm{~cm}^{-1}$ (Figure 2), in the area of $\mathrm{OH}$ stretch. Prolonging mixing time from $6-9$ mins enhances the distribution of water molecules causing an increased level of hydrogen bonding formation. The spectra in the area of $3750-2400 \mathrm{~cm}^{-1}$ is related to the $\mathrm{OH}$ stretching which is responsible for the hydrogen bonding; moreover, the intensity enhancement in these regions is probably related to hydrogen bond formation (Henrique, 2007).

Figure 2 shows that prolonging mixing time from $9-$ 18 mins results in the decrease of intensity, probably because there are existing damaged structures of the meat analog matrix when mixing time increased from 9 18 mins. The decrease in absorption band intensity is probably related to the reduction of macromolecule interaction. The research in line with this research in which prolonged shear time has resulted in the torque curve trend as the sharp torque presented an increasing and decreasing trend of stress and strain (Manski, 2008; Krintiras, 2015).

\subsection{The effect of water addition on FTIR spectra}

The FTIR spectra (Figure 3) shows that generally there is increased pattern in the intensity in all areas when water addition levels up. Probably, water does not only promote the interaction of protein-protein, but it also promotes protein-carbohydrate and carbohydrate- carbohydrate interactions. There is no different interaction in the meat analog matrix between different levels of water added as it is presented in Figure 3, where there is no different shape of FTIR spectra with different levels of water additions.

Studying protein-protein interaction of isolated soy protein from extrusion processing points out that although there are different appearances between meat analog produced with low and high-water content, there are no differences in protein-protein interaction contributing to the texturization (Chiang, 2007). An important role of water in meat analog development is in the separation of proteins, which promotes the formation of protein fibrous structure. During extrusion, when protein undergoes a plastic melt, water combined with carbohydrate would act as phase separation which enhances protein interaction (Noguchi, 1989).

\subsection{The result of response surface methodology (RSM)}

RSM is an important tool to optimize process condition for product improvement. RSM consists of a group of mathematical and statistical procedure which can reduce the number of trials and provide an approach to achieve optimization. The average values of WHC, OHC and texture of meat analog are shown in Table 2.

Multiple regression analysis is applied to the experimental data and the second order of polynomial equation for WHC value as a parameter is as follows (only coefficient with $\mathrm{p}<0.05$ (significant effect) model term are shown; $\mathrm{R}^{2}=99.3 \%$ ):

$\mathrm{Y}=476.003-3.950 \mathrm{x}_{1}-5.29 \mathrm{x}_{2}-3.056 \mathrm{x}_{3}+0.033 \mathrm{x}_{1}^{2}+0.354 \mathrm{x}_{2}^{2}+0.011 \mathrm{x}_{3}^{2}-0.053 \mathrm{x}_{1} \mathrm{x}_{2}$ $\mathrm{p}$ - values: 0.000 (intercept);0.000( $\left.\mathrm{x}_{1}\right) ; 0.120\left(\mathrm{x}_{2}\right) ; 0.001\left(\mathrm{x}_{3}\right) ; 0.000\left(\mathrm{x}_{1}^{2}\right) ; 0.021\left(\mathrm{x}_{2}^{2}\right) ; 0.004\left(\mathrm{x}_{3}^{2}\right) ; 0.018\left(\mathrm{x}_{1} \mathrm{x}_{2}\right)$ 


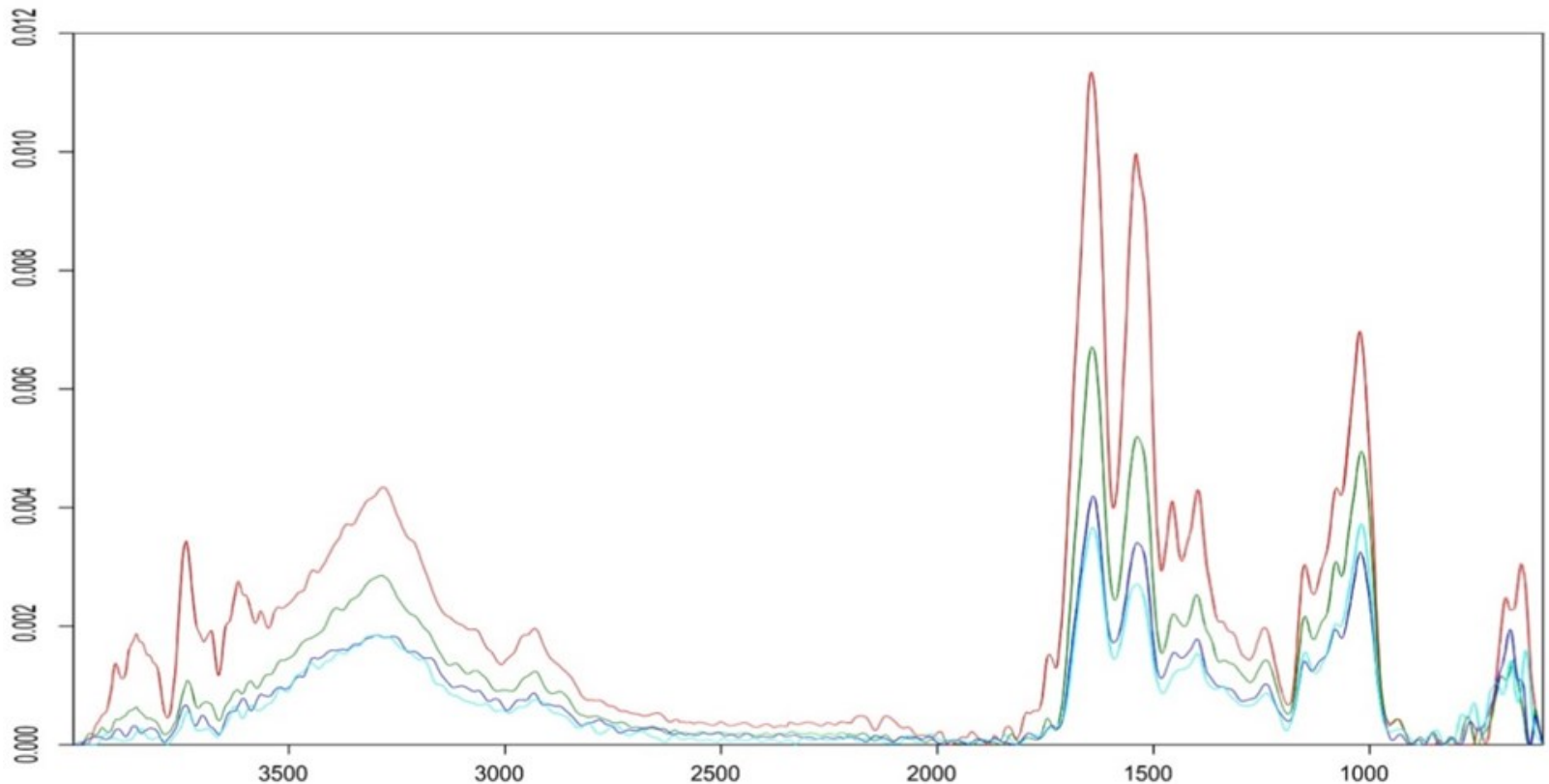

Figure 3. Spectral comparation of meat analog from 30\% XSP and 12 mins mixing time with different levels of water addition (Note: the $\mathrm{y}$ axis is absorbance units; the $\mathrm{x}$ axis is wavenumber cm-1--- $140 \% ;---120 \% ;---100 \% ;---80 \%$ ).

Where $\mathrm{Y}$ is WHC value, $\mathrm{x}_{1}$ is the variable of $\mathrm{XSP}$ proportion, $\mathrm{x}_{2}$ is the variable of mixing time and, $\mathrm{x}_{3}$ is variable of water addition.

Table 2. The result of response variables

\begin{tabular}{cccc}
\hline Samples & WHC $(\%)$ & OHC $(\%)$ & Texture $(\mathrm{gr} / \mathrm{mm})$ \\
\hline 1 & $289.08 \pm 7.36$ & $63.89 \pm 1.88$ & $28.9 \pm 0.9$ \\
2 & $154.70 \pm 6.53$ & $55.00 \pm 2.57$ & $50.1 \pm 0.3$ \\
3 & $137.89 \pm 5.57$ & $41.09 \pm 0.88$ & $107.9 \pm 1.1$ \\
4 & $115.32 \pm 3.42$ & $35.01 \pm 0.72$ & $136.9 \pm 1.1$ \\
5 & $301.21 \pm 9.23$ & $43.49 \pm 0.83$ & $12.8 \pm 0.6$ \\
6 & $264.17 \pm 2.73$ & $50.01 \pm 0.99$ & $45.7 \pm 0.4$ \\
7 & $92.99 \pm 3.47$ & $31.28 \pm 1.69$ & $108.8 \pm 1.4$ \\
8 & $155.74 \pm 7.53$ & $21.04 \pm 1.36$ & $134.8 \pm 1.1$ \\
9 & $189.67 \pm 8.63$ & $43.69 \pm 0.66$ & $64.7 \pm 1.1$ \\
10 & $182.58 \pm 4.83$ & $28.79 \pm 0.86$ & $52.1 \pm 0.7$ \\
11 & $132.16 \pm 6.73$ & $40.63 \pm 1.32$ & $99.7 \pm 0.9$ \\
12 & $126.76 \pm 8.75$ & $41.40 \pm 0.76$ & $98.9 \pm 0.9$ \\
13 & $256.08 \pm 5.78$ & $34.11 \pm 1.01$ & $49.9 \pm 1.2$ \\
14 & $133.34 \pm 5.89$ & $26.09 \pm 1.22$ & $162.0 \pm 1.2$ \\
15 & $124.49 \pm 4.89$ & $32.22 \pm 0.66$ & $119.2 \pm 0.9$ \\
\hline
\end{tabular}

Equation 1 shows that the effect of mixing time on decreasing WHC is greater than XSP proportion and water addition in the linear model terms. Although $\mathrm{p}$ value for $\mathrm{x}_{2}>0.05$, it is not eliminated from the model because it is required to support the hierarchy for $\mathrm{x}_{2}{ }^{2}$ and $\mathrm{x}_{1} \mathrm{x}_{2}(\mathrm{p}<0.05)$. A better understanding of the influence of XSP proportion, mixing time and water addition on WHC value would be described by applying descriptive technique through response surface diagram.

Figure $4 \mathrm{a}$ shows that when water is added at constant value of $110 \%$, the effect of XSP proportion is greater than the mixing time, in which an increase of XSP proportion decreases WHC. If the mixing time is set at constant level (12 mins), the effect of XSP proportion is greater than the water addition (Figure $4 b$ ). The effect of water addition is greater than the mixing time, it occurs when meat analog is produced at constant XSP proportion $(40 \%)$ (Figure $4 \mathrm{c}$ ). The conclusion of the second order of polynomial data and descriptive technique is XSP proportion having the greatest effect on WHC value.

WHC is an important character of fresh meat since it affects the quality of the end product. Polysaccharides are extensively used as ingredients in a number of meat products to obtain desirable binding characteristics, texture and appearance (Perez-Mateos and Montero, 2000). The effect of polysaccharides on WHC has been widely studied. The addition of sodium alginate into pork muscle gel enhances WHC (Cong-Gui et al., 2006). The effect of soy protein concentrate on WHC is better than xanthan gum when added to silver carp surimi (Hasanpour et al., 2012). WHC of proteins is affected by their interaction with carbohydrate (Tolstoguzov, 1997). The result of this research showed that the addition of XSP as a carbohydrate source in meat analog matrix decreased WHC significantly.

The second order of polynomial equation for $\mathrm{OHC}$ value as an individual parameter is as follows (only coefficients with $\mathrm{p}<0.05$ (significant effect) model term are shown, and $\mathrm{R}^{2}=99.7 \%$ ):

$\mathrm{Y}=5.695+0.140 \mathrm{x}_{1}+0.981 \mathrm{x}_{2}+0.308 \mathrm{x}_{3}-0.001 \mathrm{x}_{1}^{2}-0.001 \mathrm{x}_{3}^{2}-0.022 \mathrm{x}_{1} \mathrm{x}_{2}+0.009 \mathrm{x}_{2} \mathrm{x}_{3}$ $\mathrm{p}$ - values: $0.274\left(\right.$ intercept); $0.006\left(\mathrm{x}_{1}\right) ; 0.042\left(\mathrm{x}_{2}\right) ; 0.004\left(\mathrm{x}_{3}\right) ; 0.002\left(\mathrm{x}_{1}^{2}\right) ; 0.003\left(\mathrm{x}_{3}^{2}\right) ; 0.000\left(\mathrm{x}_{1} \mathrm{x}_{3}\right) ; 0.005\left(\mathrm{x}_{2} \mathrm{x}_{3}\right)$ Where $\mathrm{Y}$ is $\mathrm{OHC}$ value, $\mathrm{x}_{1}$ is the variable of $\mathrm{XSP}$ proportion, $x_{2}$ is the variable of mixing time and, $x_{3}$ is variable of water addition.

Equation 2 shows that the effect of mixing time on increasing $\mathrm{OHC}$ is greater than water addition and XSP 


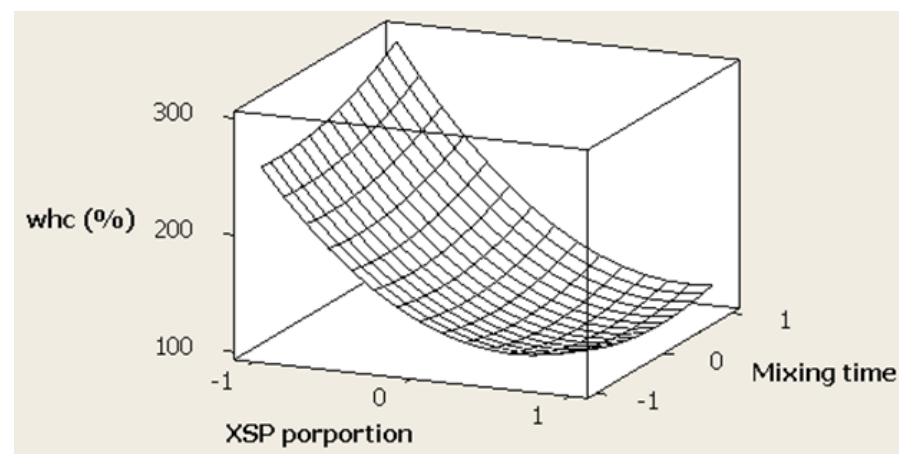

Figure 4a. Surface plot of WHC vs. mixing time; XSP proportion.

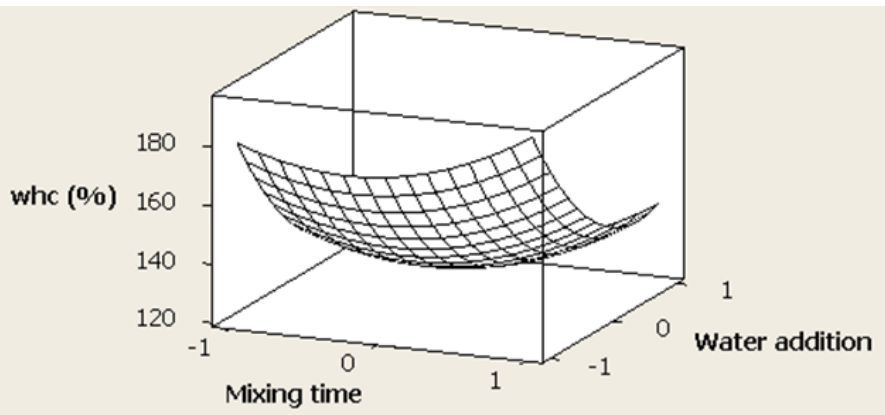

Figure 4c. Surface plot of WHC vs. water addition; mixing time.

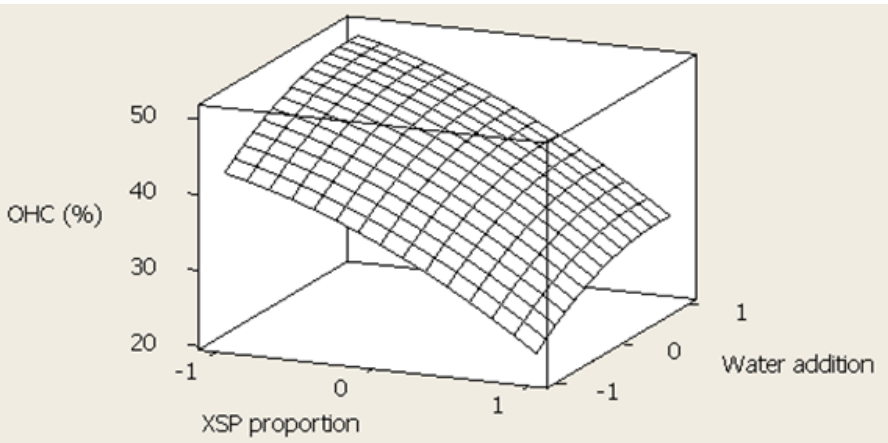

Figure 5b. Surface plot of OHC vs. water addition; XSP proportion.

proportion in the linear model terms and is also greater than those of other factors. The effect of XSP proportion, mixing time and water addition on $\mathrm{OHC}$ is clearly described by applying a descriptive technique through response surface diagram. Figure 5a shows that at constant water addition, prolonging mixing time increases the effect of XSP proportion on leveling down OHC. The enhancement of XSP proportion decreases the effect of mixing time on increasing $\mathrm{OHC}$. If mixing time is set at constant level, the effect of XSP proportion decreases the $\mathrm{OHC}$, but water addition increases the $\mathrm{OHC}$, in which the effect of XSP proportion is greater (Figure 5b). Figure $5 \mathrm{c}$ shows that the effects of mixing time and water addition were almost linear in increasing OHC when XSP proportion is constant $(40 \%)$. This result can be confirmed with Equation 2, in which the term of $\mathrm{X}_{2}^{2}$ has been deleted from the equation.

The WHC and OHC are functional properties of the meat which depends on pore size and the charges of molecules. High OHC indicates the enhanced

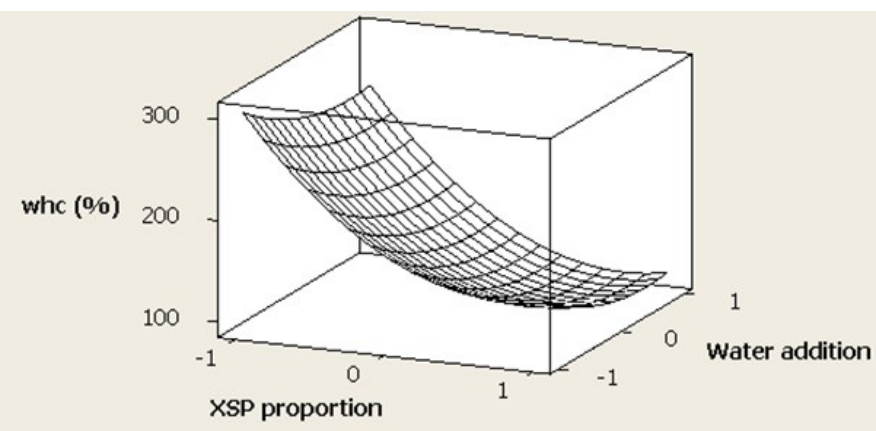

Figure 4b. Surface plot of WHC vs. water addition; XSP proportion.

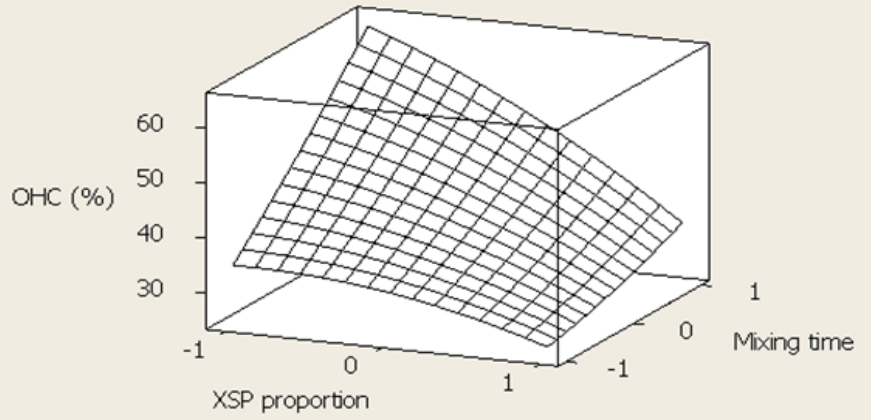

Figure 5a. Surface plot of OHC vs. mixing time; XSP proportion.

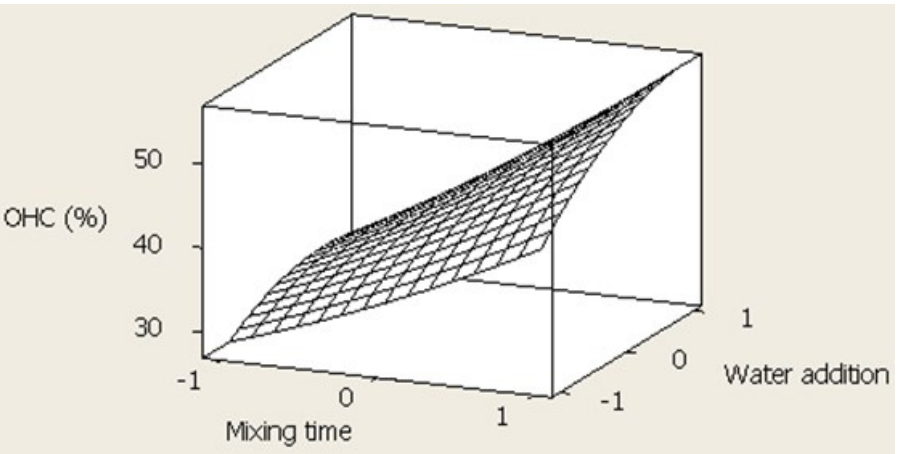

Figure 5c. Surface plot of $\mathrm{OHC}$ vs. water addition; mixing time.

hydrophobic character of proteins, causing fat physically bind with protein by capillary attraction. The protein exposes non-polar amino acids and enhances hydrophobicity as a result in increasing oil absorption (Akinyede and Amoo, 2009). OHC is important properties in meat products like sausages and effects on shelf life (Chen et al., 2006). Therefore, meat analog with highest $\mathrm{OHC}$ is favorable in sausage formulations where high $\mathrm{OHC}$ is required.

Multiple regression analysis is applied to the experimental data and the second order of polynomial equation for texture value as an individual parameter is as follows (only coefficients with $\mathrm{p}<0.05$ (significant effect) model term are shown; $\mathrm{R}^{2}=97.8 \%$ ):

$\mathrm{Y}=283.655+2.279 \mathrm{x}_{1}+7.224 \mathrm{x}_{2}+4.905 \mathrm{x}_{3}-0.015 \mathrm{x}_{3}^{2}-0.009 \mathrm{x}_{1} \mathrm{x}_{3}-0.085 \mathrm{x}_{2} \mathrm{x}_{3}$

$\mathrm{p}$ - values: 0.000 (intercept); $0.000\left(\mathrm{x}_{1}\right) ; 0.008\left(\mathrm{x}_{2}\right) ; 0.000\left(\mathrm{x}_{3}\right) ; 0.001\left(\mathrm{x}_{3}^{2}\right) ; 0.010\left(\mathrm{x}_{1} \mathrm{x}_{3}\right) ; 0.002\left(\mathrm{x}_{2} \mathrm{x}_{3}\right)$

Where $\mathrm{Y}$ is texture value, $\mathrm{x}_{1}$ is the variable of XSP proportion, $x_{2}$ is the variable of mixing time and, $x_{3}$ is variable of water addition. 
Equation 3 shows that the effect of mixing time on increasing texture is greater than water addition and XSP proportion in the linear model terms, but the $\mathrm{p}$-value for $\mathrm{X}_{2}$ (mixing time) coefficient is greater than 0.05 . Therefore, water addition has the greatest influence on texture. The effect of XSP proportion, mixing time and water addition on texture is clearly described by applying descriptive technique through response surface diagram.

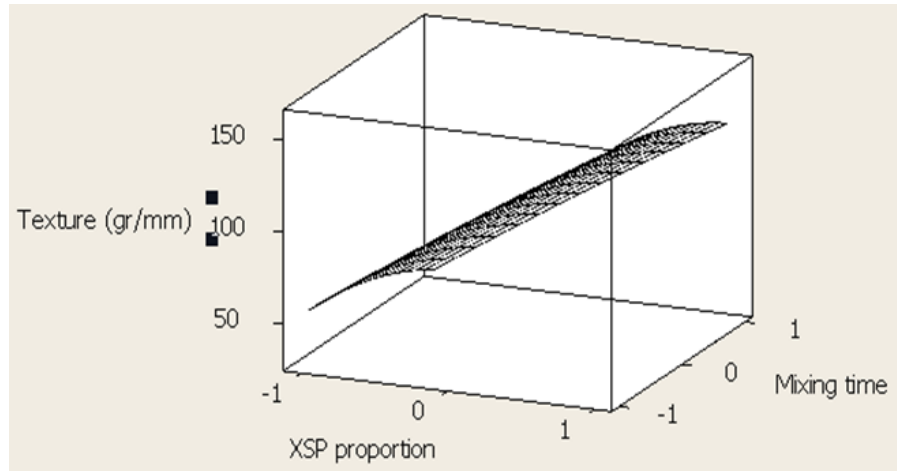

Figure 6a. Surface plot of texture vs. mixing time; XSP proportion.

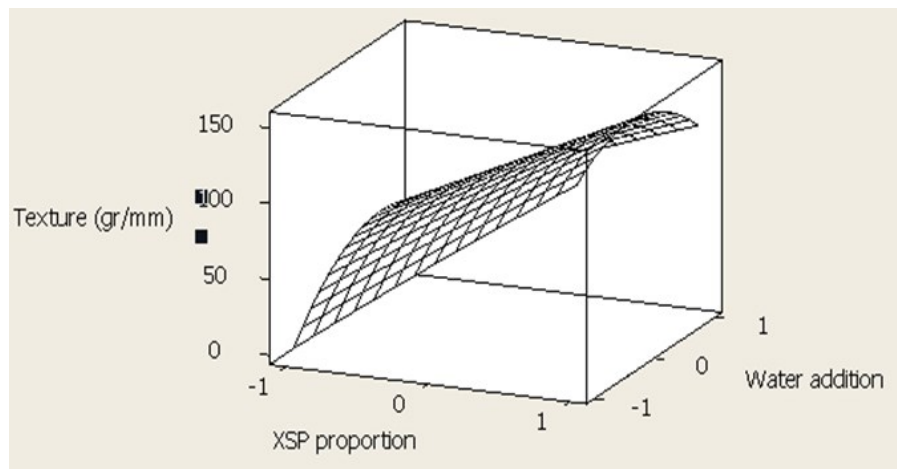

Figure 6b. Surface plot of texture vs. water addition; XSP proportion.

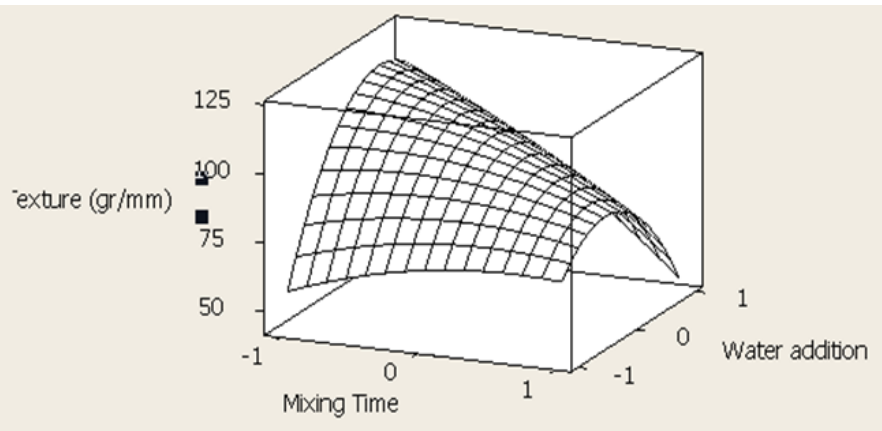

Figure 6c. Surface plot of Texture vs. water addition; mixing time.

Figure $6 \mathrm{a}$ and Figure $6 \mathrm{~b}$ show that the effect of XSP proportion is linear at both constant water addition and mixing time. Equation 3 confirms with the term $\mathrm{X}_{1}{ }^{2}$ deletion. Figure $6 \mathrm{a}$ and Figure $6 \mathrm{c}$ show the same tendency for mixing time when both water addition and XSP proportion are set at constant level. Equation 3 confirmed with the term $\mathrm{X}_{2}^{2}$ deletion. The effect of water addition was quadratic. It is presented in Equation 3 that there is the term of $\mathrm{X}_{3}^{2}$. Figure $6 \mathrm{c}$ shows that there is a different effect of mixing time on texture when water is added at different levels. At low water addition, prolonging mixing time slightly increases texture, but at high water addition, the result is in contrast, in which prolonging mixing time decreases texture.

The optimum conditions and predicted responses are presented in Table 3. For convenience for the production process, the optimum conditions are modified to XSP proportion of $30 \%$, water addition of $140 \%$ and mixing time of 12 mins. The WHC value of the meat analog produced from this research is highly similar to pork muscle gel from another research conducted by Chen et al. (2006) and is lower than Isolated Soy Protein from the research conducted by Kempka et al. (2014).

\section{Conclusion}

Meat analog can be produced from the mixing of concentrated soy protein and Xanthosoma sagittifolium powder with the application of household pasta machine. The FTIR spectra show that $20 \%$ of XSP proportion, 9 minutes of mixing time and $140 \%$ of water addition have the highest absorption intensity. This result is probably related to the interaction of macromoleculemacromolecule and macromolecule-water. XSP proportion, mixing time and water addition become the significant factors affecting on water holding capacity, oil holding capacity and meat analog texture. The XSP proportion has the greatest effect on those three parameters. The optimal operation condition in meat analog production is XSP proportion of $30 \%$, water addition of $140 \%$ and mixing time of 12 mins. The characters of the meat analog produced are $145.3542 \pm 5.7384 \%$ of WHC, $43.7869 \pm 7.8725 \%$ of $\mathrm{OHC}$ and $90.32 \pm 0.37 \mathrm{gr} / \mathrm{mm}$ of texture.

\section{Conflict of Interest}

The authors declare no conflict of interest.

\section{Acknowledgments}

This work is financially supported by Research and Technology, Higher Education, Ministry of Indonesia Government.

\section{References}

Akinyede, A.I. and Amoo I.A. (2009). Chemical and Functional Properties of Full Fat and Defatted Cassia Fistula Seed Flours. Pakistan Journal of Nutrition, 8 (6), 765 - $769 . \quad$ https://doi.org/10.3923/ pjn.2009.765.769

Bodirlau, R. and Teaca, C.A. (2009). Fourier Transform InfraRed Spectroscopy and Thermal Analysis of Lignocellulose Fillers Treated with Organic Anhydrides. Romanian Journal of Physics, 54(1), 93 
-104 .

Chau, C. F., Cheung, P.C.K. and Wong, Y.S. (1997). Functional Properties of Protein Concentrates from Three Chinese Indigenous Legume Seeds. Journal of Agricultural and Food Chemistry, 45(7), 2500 2503. https://doi.org/10.1021/jf970047c

Chen C.G., Gerelt, B., Jiang, S.T., Nishiumi, T. and Suzuki, A. (2006). Effects of High Pressure on Ph, Water-Binding Capacity and Textural Properties of Pork Muscle Gels Containing Various Levels of Sodium Alginate. Asian-Australia Journal of Animal Science, 19(11), 1658-1664. https://doi.org/10.5713/ ajas.2006.1658

Chiang, A. (2007). Protein-Protein Interaction of Soy Protein Isolate from Extrusion Processing. Columbia, USA: University of Missouri, MSc. Thesis

Cong-Gui, C., Gerelt, B., Shao-Tong, J., Nishiumi, T. and Suzuki, A. (2006). Effects of high pressure on $\mathrm{pH}$, water-binding capacity and textural properties of pork muscle gels containing various levels of sodium alginate. Asian-Australia, Journal of Animal Science, 19(11), 1658 - 1664. https://doi.org/10.5713/ ajas.2006.1658

Coomaraswamy, M. and Flint, F.O. (1973). The Histochemical Detection of Soya 'Novel Proteins' in Comminuted Meat Products. Analyst, 98, 542-545. https://doi.org/10.1039/an9739800542

Hager, D.F. (1984). Effects of Extrusion upon Soy Concentrate Solubility. Journal of Agriculture and Food Chemistry, 32, 293-296. https:// doi.org/10.1021/jf00122a029

Hasanpour F., Hoseini, E., Motalebi, A.A. and Darvish, F. (2012). Effect of Soy Protein Concentrate an Xanthan Gum on Physical Properties of Silver Carp (Hypophthalmichthys molitrix) Surimi. Iranian Journal of Fisheries Sciences, 11(3), 518-530

Henrique C.M., Te'ofilo, R.F., Sabino, L., Ferreira, M.M.C. and Cereda, M.P. (2007). Classification of Cassava Starch Films by Physicochemical Properties and Water Vapor Permeability Quantification by FTIR and PLS. Journal of Food Science, 72(4), 184 $189 . \quad$ https://doi.org/10.1111/j.17503841.2007.00342.x

Huang, C.B., Jeng, R., Sain, M., Saville, B. and Hubbes, M. (2006). Production, Characterization and Mechanical Properties of Starch Modified by Ophiostoma spp. BioResources, 1 (2), 257-269.

Kempka, A.P., Honaiser, T.C., Fagundes, E. and Prestes, R.C. (2014). Functional Properties of Soy Protein Isolate of Crude and Enzymatically Hydrolyzed at Different Times. International Food Research
Journal, 21(6), 2229-2236.

Kong, J. and Yu, S. (2007). Fourier Transform Infrared Spectroscopic Analysis of Protein Secondary Structures. Acta Biochimica et Biophysica Sinica, 39 (8), 549-559. https://doi.org/10.1111/j.17457270.2007.00320.x

Krintiras, G.A., Göbel, J., Van der Goot, A.J. and Stefanidis, G.D. (2015). Production of Structured Soy-Based Meat Analogues Using Simple Shear and Heat in a Couette cell. Journal of Food Engineering, 160, 34-41. https://doi.org/10.1016/ j.jfoodeng.2015.02.015

Lin, S.H., Huff, E. and Hsieh, F. (2000). Texture and Chemical Characteristics of Soybean Protein Meat Analog Extruded at High Moisture. Journal of Food Science, 65(2), 264-269. https://doi.org/10.1111/ j.1365-2621.2000.tb15991.x

Manski, J.M., van der Zalm, E.E.J., van der Goot, A.J. and Boom, R.M. (2008). Influence of Process Parameters on Formation of Fibrous Materials from Dense Calcium Caseinate Dispersions and Fat. Food Hydrocolloids, 22(4), 587-600. https:// doi.org/10.1016/j.foodhyd.2007.02.006

Maurice, T.J. and Stanley, D.W. (1978). TextureStructure Relationships in Texturized Soy Protein Iv. Influence of Process Variables on Extrusion Texturization. Canadian Institute of Food Science and Technology Journal, 11(1), 1- 6. https:// doi.org/10.1016/S0315-5463(78)73151-2

Noguchi, A. (1989). Extrusion Cooking of HighMoisture Protein Foods. In Mercier, C., Linko, P. and Harper, J.M. (eds.). Extrusion cooking. American Association of Cereal Chemists: St. Paul, Minnesota.

Owuamanam, C.I., Ihediohanma, N.C. and Nwanekezi, E.C. (2010). Sorption Isotherm, Particle Size, Chemical and Physical Properties of Cocoyam Corm Flours. Researcher, 2(8), 11-19.

Perez-Mateos, M. and Montero, P. (2000). Contribution of Hydrocolloids to Gelling Properties of Blue Whiting Muscle. European Food Research and Technology, 210, 383-390. https://doi.org/10.1007/ s002170050568

Rareunrom, K., Tongta, S. and Yongsawatdigul, J. (2008). Effects of Soy Protein Isolate on Chemical and Physical Characteristics of Meat Analog. Asian Journal of Food and Agro-Industry, 1(2), 97-104.

Senanayake, S.A., Ranaweera, K.K.D.S., Bamunuarachchi, A. and Gunaratne, A. (2012). Proximate Analysis and Phytochemical and Mineral Constituents in Four Cultivars of Yams and Tuber Crops in Sri Lanka. Tropical Agricultural Research 
and Extension, 15(1), 32-36. http:// dx.doi.org/10.4038/tare.v15i1.5240

Sheard, P.R., Ledward, D.A. and Mitchell, J.R. (1984). Role of Carbohydrates in Soya Extrusion. Journal of Food Technology, 19(4), 475 - 483. https:// doi.org/10.1111/j.1365-2621.1984.tb00371.x

Tolstoguzov, V.B. (1997). Protein-Polysaccharide Interactions. In Damodaran, S. and Paraf, A. (Ed). Food proteins and their applications., p. 171-256. New York, USA: Marcel Dekker. https:// doi.org/10.1201/9780203755617-6

Yao, G., Liu, K.S. and Hsieh, F. (2004). A New Method for Characterizing Fiber Formation in Meat Analogs During High Moisture Extrusion. Journal of Food Science 69(7), 303-307. https://doi.org/10.1111/ j.1365-2621.2004.tb13634.x 